\title{
Unsteady conjugated heat transfer in cylinder of highly loaded opposed-piston engine
}

\begin{abstract}
Paper presents a method of calculating the temperature distribution in cylinder for a 2-stroke, opposed-piston (OP) internal combustion engine (ICE). Development of such machines has been very limited after World War II due to technological and ecological problems [9], therefore progress in numerical modeling for analyzing highly boosted OP engines was also halted. Current technology permits returning to the OP arrangement, where due to better combustion chamber shape it is potentially possible to achieve higher thermodynamic efficiency than in arrangement with the cylinder head [9, 10]. Authors decided to use a general purpose CFD-program (in this case Ansys Fluent) coupled with additional tools to calculate conjugated heat transfer between the load in the cylinder and the cylinder itself to get a $3 D$ temperature distribution in solid body.
\end{abstract}

Key words: internal combustion engines, conjugated heat transfer, Ansys Fluent, MathWorks Matlab, scripting

\section{Nieustalona sprzężona wymiana ciepla w cylindrze wysoko obciążonego silnika o tłokach przeciwbieżnych}

\begin{abstract}
Artykut prezentuje metode wyznaczania temperatury cylindra dla dwusuwowego silnika wewnętrznego spalania o tłokach przeciwbieżnych (opposed piston-OP). Rozwój takich maszyn po II wojnie światowej zostat mocno ograniczony z powodu problemów technologicznych i ekologicznych [9] i w zwiazku z tym rozwój modelowania numerycznego, w celu analizy wysoko doładowanych silników typu OP, również został zahamowany. Obecny rozwój techniki pozwala powrócić do konstrukcji typu OP, w których z racji korzystniejszego ksztaltu komory spalania możliwe jest uzyskanie potencjalnie większej sprawności termodynamicznej niż w układzie z głowica [9, 10]. Do obliczenia wymiany ciepła między ładunkiem $w$ cylindrze a cylindrem, by otrzymać trójwymiarowy rozkład temperatury w ciele statym, wykorzystano programu CFD ogólnego zastosowania (w tym przypadku Ansys Fluent) sprzężony z dodatkowymi narzędziami.

Słowa kluczowe: silniki spalinowe, sprzężona wymiana ciepła, Ansys Fluent, MathWorks Matlab, skryptowanie
\end{abstract}

\section{Introduction}

OP engines allow achieving high thermodynamic efficiency inter alia due to lack of a cylinder head and better shape of the combustion chamber $[9,10]$. This feature makes them interesting for present-day companies like EcoMotors or AchatesPower, which are intensively developing their own prototypes. Geometry and requirements for OP engines cooling system varies greatly from requirements for conventional 4-stroke engines, thus it is required to develop a specific approach to the analysis of heat transfer, which in this article is understood as calculation of the temperature distribution in cylinder (Fig. 1).

Combustion chamber. Heat load is highly concentrated in the middle of cylinder, combustion chamber is formed between two moving pistons. There is no additional cooling scavenging cycle like in standard 4-stroke engines. To take full advantage of OP combustion chamber shape, i.e. higher ratio of a volume to area (volume to area $\sim$ heat generation to heat loses) designer should focus on increasing the average temperature (and pressure) of working medium, thus designing the appropriate cooling system becomes a critical issue from the point of view of increasing the thermodynamic efficiency.

Exhaust ports. The exhaust ports are exposed to hot combustion gases for about $120^{\circ}$ crank angle degree (CAD)

\section{Wprowadzenie}

Silniki o tłokach przeciwbieżnych umożliwiają osiągniecie dużej sprawności termodynamicznej między innymi z braku klasycznej głowicy oraz korzystniejszego kształtu komory spalania $[9,10]$. Te cechy sprawiają, że silniki takie stają się obiektem zainteresowania współczesnych firm, takich jak EcoMotors i AchatesPower, które intensywnie rozwijają swoje prototypy. Geometria oraz wymagania stawiane układom chłodzenia silników OP znacznie różnią się od wymagań stawianych standardowym silnikom 4-suwowym, wobec tego konieczne jest opracowanie specjalnego podejścia do analizy wymiany ciepła, rozumianej w tym artykule jako wyznaczanie rozkładu temperatury w cylindrze (rys. 1).

Komora spalania. Obciążenie cieplne jest bardzo skoncentrowane w środku cylindra, komora spalania jest formowana pomiędzy dwoma przemieszczającymi się tłokami. Brak jest dodatkowego chłodzącego cyklu wymiany ładunku tak jak w silniku 4-suwowym. By w pełni wykorzystać zalety kształtu komory spalania silnika OP, to znaczy otrzymać większy stosunek objętości do powierzchni (objętość do powierzchni $\sim$ wydzielanie ciepła do strat), konstruktor takiego silnika powinien skupić się na zwiększeniu średniej temperatury (oraz ciśnienia) czynnika roboczego. Z tego 
which makes thermal stress and creeping phenomena a serious issue. Minimizing the pressure loses during scavenging forces using wider ports, which on the other hand makes the ports bridges more fragile and therefore more vulnerable to wear during long-term work.

Cylinder liner. Liner's temperature should not be higher than $523 \mathrm{~K}$, because it is the limit above which the lubricant film is degraded [7]. Again, no extra cooling stroke makes whole cylinder liner more hot in a 2 -stroke than in a similar 4-stroke engine.

Assuming, that since the start of the engine achieving a stable temperature distribution of the cylinder takes at least 5 minutes of work the engine would have to perform 7500 working cycles (considering 1500 RPM) to heat from ambient to working temperature. Simulating the process explicitly would force calculating 7500 cycles of the full 3D CFD model to get the right temperature distribution, which would take an unacceptable amount of time - approx. 40 years on a workstation. Authors decided to accelerate the calculation process by dividing the conjugated heat transfer in two simpler cases:

a) (model A) 3D unsteady simulation of one, full engine cycle in the computational domain consisting of a fluid and a solid. Its objective is to get the heat fluxes from fluid to solid (in this simulation there is 14 degrees of freedom per cell with simplified combustion using species transport).

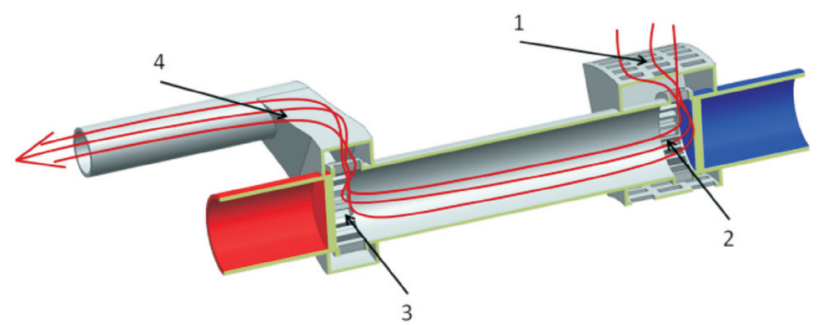

Fig. 1. Flow pattern in an uniflow OP engine, 1 - intake, 2 - intake ports, 3 - exhaust ports, 4 - exhaust

Rys. 1. Przepływ ładunku w silniku o plukaniu wzdlużnym o tłokach przeciwbieżnych, 1 - przelotnia, 2 - kanaly dolotowe, 3-kanaly wylotowe, $4-$ wydech

b) (model B) A simplified 3D simulation of heat transfer in the calculation domain consisting only of a cylinder solid (there is only 1 degree of freedom per cell - temperature), with heat fluxes as fluid $\mathrm{BC}$ from inside, and convection from outside.

The first attempt was made with a simple cylinder without a cooling system to test the method and to draw preliminary conclusions which will help design the final version of the cooling system. One work cycle of the model A was computed once per 1500 work cycles of the model B.

Initial cylinder temperature was set to $500 \mathrm{~K}$ in the whole volume of solid, heat fluxes obtained from the full engine cycle simulation (model A), modified in a proper way and transferred to a simplified solid model (model B). After 1500 cycles (1 minute of engine's work) the temperature distribution in the solid was transferred back to the model A after względu dobranie odpowiedniego układu chłodzenia staje się krytyczne z punktu widzenia zwiększania sprawności termodynamicznej.

Kanały wylotowe. Kanały wylotowe są narażone na gorące spaliny przez około $120^{\circ}$ obrotu wału korbowego (OWK), co czyni zjawiska takie jak naprężenia cieplne lub pełzanie poważnym problemem. Minimalizacja strat ciśnienia podczas wymiany ładunku wymusza stosowanie szerszych okien, ale powoduje to, że mostki między kanałami stają się delikatniejsze, a przez to bardziej narażone na zniszczenie długotrwałą pracą.

Powierzchnia cylindra. Temperatura powierzchni cylindra nie powinna przekraczać $523 \mathrm{~K}$, gdyż jest to granica, powyżej której film smarny ulega degradacji [7]. Ponownie, brak dodatkowego cyklu na chłodzenie czyni powierzchnię cylindra bardziej gorącą w silniku dwusuwowym niż w podobnym silniku czterosuwowym.

Przyjmując, że od momentu rozruchu silnika osiągnięcie stabilnej temperatury cylindra zajmuje co najmniej 5 minut pracy, wtedy silnik musiałby wykonać 7500 cykli pracy przy 1500 obrotach na minutę, aby nagrzać się od temperatury otoczenia do temperatury roboczej. Symulując ten proces wprost, należałoby policzyć 7500 cykli pracy w pełnym, trójwymiarowym modelu CFD, aby uzyskać właściwy rozkład temperatury, co zajęłoby nieakceptowalną ilość czasu - ok. 40 lat na stacji roboczej. W badaniach autorskich zdecydowano się przyspieszyć proces obliczeniowy przez podzielenie sprzężonej wymiany ciepła na dwa prostsze przypadki:

a) (model A) trójwymiarowa, nieustalona symulacja jednego, pełnego cyklu pracy silnika $\mathrm{w}$ domenie obliczeniowej składającej się z płynu oraz ciała stałego. Jej celem jest uzyskanie strumieni ciepła od płynu do ciała stałego (w tej symulacji występuje 14 stopni swobody na objętość kontrolną przy uproszczonym spalaniu z modelem transportu cząstek);

b) (model B) uproszczona, trójwymiarowa symulacja wymiany ciepła $w$ domenie obliczeniowej składającej się tylko z ciała stałego cylindra (występuje tylko jeden stopień swobody na objętość kontrolną - temperatura), ze strumieniami ciepła od płynu jako wewnętrzny warunek brzegowy oraz konwekcją na zewnątrz.

Pierwsze podejście wykonano z prostym cylindrem bez układu chłodzenia, tak aby przetestować metodę oraz wyciągnąć wnioski, które będą pomocne przy projekcie finalnej wersji układu chłodzenia. Jeden cykl pracy w modelu A był obliczany na 1500 cykli pracy w modelu B.

Początkową temperaturę cylindra ustawiono w całej objętości ciała stałego na $500 \mathrm{~K}$, strumienie ciepła pobrano z symulacji pełnego cyklu pracy silnika (model A), odpowiednio zmodyfikowano i przetransferowano do uproszczonego modelu ciała stałego (model B). Po 1500 cyklach (1 minucie pracy silnika) rozkład temperatury w ciele stałym został przeniesiony z powrotem do modelu $\mathrm{A}$, a następnie obliczono nowe strumienie ciepła oraz rozkłady temperatury. Ten proces był iterowany dopóki temperatura przestała się zmieniać (za próg ustalono $5 \mathrm{~K}$ ) w modelu ciała stałego (model B). W powyższy sposób otrzymano wstępny roz- 
which new heat fluxes and temperatures were calculated. This procedure has been iterated until the temperature distribution stopped changing (threshold was set to $5 \mathrm{~K}$ ) in the cylinder solid model (model B). In this manner the initial temperature distribution of the design of the cooling system (it took six iterations) was obtained.

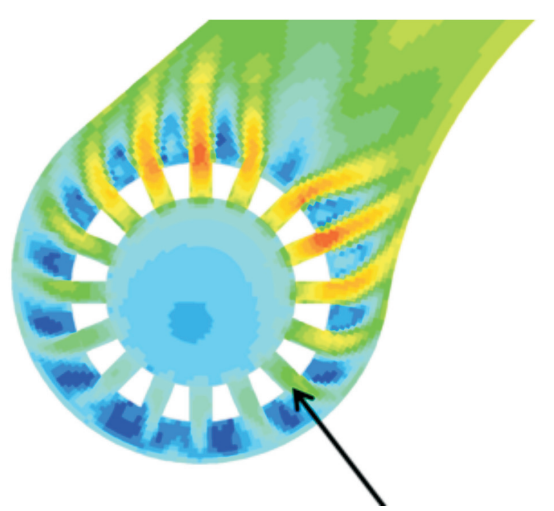

Fig. 2. Asymmetrical flow (for an unoptimized exhaust)

Rys. 2. Niesymetryczny przeplyw (dla niezoptymalizowanego wydechu)

In contrast to [7] the in-cylinder parameters like heat flux, gas temperature etc. were calculated locally using CFD, not modeled globally by Nusselt number correlations. This approach was needed to get a full 3D distribution and reflect the flow asymmetry (Fig. 2) in an asymmetrical temperature distribution which is very important as the temperature gradients are the main sources of mechanical stresses in such engines.

\section{Scavenging and combustion}

Scavenging is a process of pushing exhausted gas charge out of the cylinder and drawing in the fresh air or air-fuel mixture. Scavenging is particularly important for two-stroke engines, as intake and exhaust occurs at the same time (valve overlap lasts usually about $120^{\circ} \mathrm{CA}$ ).

The most effective scavenging method is uniflow scavenging (Fig. 3), which is also the most popular among highly efficient 2 -stroke crosshead marine combustion engines. The analyzed OP engine is piston ported, that means intake and exhaust ports are opened and closed by moving pistons.

Unsteady 3D simulation of the full engine cycle with simplified combustion (model A) was used to get a temperature distribution in the space and time of in-cylinder charge (Fig. 4) and to get heat fluxes to/from the cylinder walls.

Compression was starting after closing the intake and exhaust ports. The mass averaged temperature, pressure and composition of the in-cylinder charge were exported from Ansys Fluent. These values were the input parameters to a script of Cantera program, which was simulating the compression and combustion outside of Ansys Fluent. Results (pressure, adiabatic temperature after combustion and mixture composition) have been overwritten in the cylinder volume for the top dead center piston position, while the velocity field was not modified. Mixture then underwent expansion, the ports opened and another scavenging cycle was beginning. kład temperatury do projektu układu chłodzenia (zajęło to 6 iteracji).

W przeciwieństwie do danych z publikacji [7] parametry w cylindrze, takie jak strumienie ciepła, temperatura gazu itp. były obliczane lokalnie przy wykorzystaniu CFD, niemodelowane globalnie korelacjami liczby Nusselta. Takie podejście było konieczne, by otrzymać trójwymiarowe rozkłady oraz odzwierciedlić niesymetryczność przepływu (rys. 2) w niesymetrycznym rozkładzie temperatury, który jest bardzo istotny, ponieważ gradienty temperatury są w silnikach tego typu głównym źródłem naprężeń mechanicznych.

\section{Wymiana ladunku i spalanie}

Wymiana ładunku jest to proces polegający na usuwaniu produktów spalania z cylindra oraz napełnianiu cylindra świeżym powietrzem lub mieszaniną paliwowo-powietrzną. Wymiana ładunku jest szczególnie istotna dla silników dwusuwowych, ponieważ opróżnianie i napełnianie zachodzą w tym samym czasie (przekrycie zaworowe trwa zwykle około $120^{\circ} \mathrm{OWK}$ ).

Najbardziej efektywnym typem wymiany ładunku jest płukanie wzdłużne (rys. 3), które jest także najbardziej popularne wśród wysoko sprawnych wodzikowych okrętowych dwusuwowych silników spalinowych. Analizowany silnik OP nie posiada typowych zaworów, okna dolotowe i wylotowe $z$ cylindra są otwierane i zamykane przemieszczającymi się tłokami.
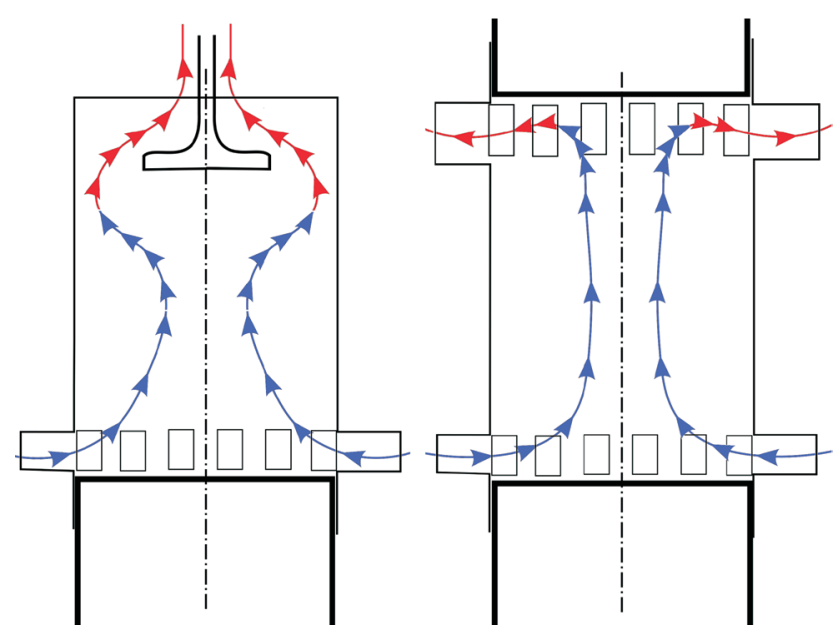

Fig. 3. Uniflow scavenging - exhaust with valve control (left) or piston ported (right)

Rys. 3. Plukanie wzdluzine-wylot otwierany zaworem (z lewej) lub tlokiem (z prawej)

Nieustalona trójwymiarowa symulacja pełnego cyklu pracy silnika z uproszczonym spalaniem (model A) została użyta, aby uzyskać rozkład w przestrzeni i czasie ładunku w cylindrze (rys. 4) oraz do pozyskania strumieni ciepła ze ścianek oraz do ścianek cylindra.

Po zamknięciu kanałów dolotowych oraz wylotowych zaczynał się proces sprężania. Z programu Ansys Fluent eksportowano uśrednioną masowo temperaturę, ciśnienie oraz skład mieszanki wewnątrz cylindra. Te wielkości były parametrami wejściowymi do autorskiego skryptu programu 


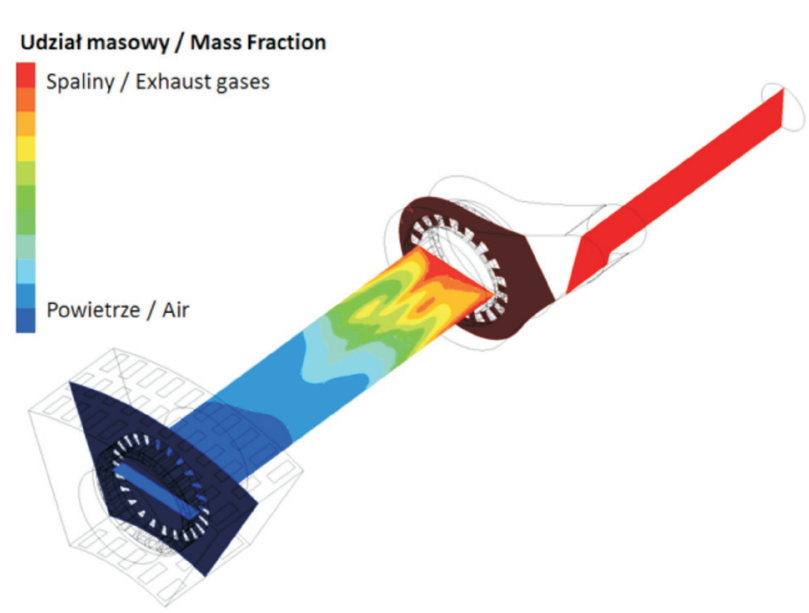

Fig. 4. A typical exhaust gas distribution during scavenging $\left(\mathrm{CO}_{2}\right.$ as a marker)

Rys. 4. Typowy rozktad spalin podczas przeptukiwania $\left(\mathrm{CO}_{2}\right.$ jako marker)

Accurate combustion modeling was not justified at this stage as the wall temperature has big impact on the combustion process and should be a result of, not an input for the heat transfer simulation. Moreover, it would prevent carrying out the calculations in an acceptable time.

Below the settings of a 3D full engine cycle simulation are presented (model A).

Mesh statistic:

Cells (Fig. 5) - min.756000@TDC, max $1300000 @$ BDC

Worst element orthogonal quality (Ansys Fluent) -0.37

Scavenging CFD settings:

Solver Type - Transient Pressure-Based

Turbulence - SST k-omega (default)

Dynamic mesh - layering with custom motion

Solving scheme - Pressure-Implicit with Splitting of Operators (PISO)

Spatial Discretization - default

Transient formulation - First Order Implicit + Non-Iterative Time-Advancement

Time step - 3600 time steps/cycle $\left(0.1^{\circ} \mathrm{CAD}\right)$.

Domains - solid + fluid

Detailed scavenging modeling approach can be found in [6].

\section{Heat flux export and modification}

When solving a 3D engine full cycle (model A) the heat fluxes and temperature distribution on the walls were exported from Ansys Fluent to external data file every 10 time steps $\left(1{ }^{\circ} \mathrm{CAD}\right)$. Heat fluxes and temperature profiles were parsed into Matlab and collected into proper structure containing information about wall name, current time, position and valu

Lubrication oil. Taking into account the impact of the lubricating oil in the gap between the piston and the cylinder would force to mesh a $0.03 \mathrm{~mm}$ gap with at least few elements (while the cylinder diameter is about $50 \mathrm{~mm}$ ). Resulting mesh size would make such transient case unsolvable on
Cantera, który symulował sprężanie i spalanie występującej w cylindrze mieszanki poza programem Ansys Fluent. Wyniki (ciśnienie, temperatura adiabatyczna po spalaniu oraz skład mieszanki) były nadpisywane w objętości cylindra symulacji w programie Ansys Fluent dla górnego martwego położeniu tłoka, podczas gdy pole prędkości nie było modyfikowane. Mieszanka następnie ulegała rozprężeniu, otwierały się kanały i zaczynał się kolejny cykl wymiany ładunku.

Dokładne modelowanie spalania nie było uzasadnione na tym etapie, ponieważ temperatura ścianki ma duży wpływ na przebieg spalania i powinna być wynikiem, nie warunkiem brzegowym dla symulacji wymiany ciepła. Dodatkowo uniemożliwiłoby to przeprowadzenie obliczeń w akceptowalnym czasie.

Poniżej przedstawiono ustawienia trójwymiarowej symulacji pełnego cyklu pracy silnika (model A).

Statystyki siatki:

Objętości skończone (rys. 5): min.756000@GMP, maks. 1300 000@DMP

Wskaźnik orthogonal quality (Ansys Fluent) dla najgorszego elementu: 0.37

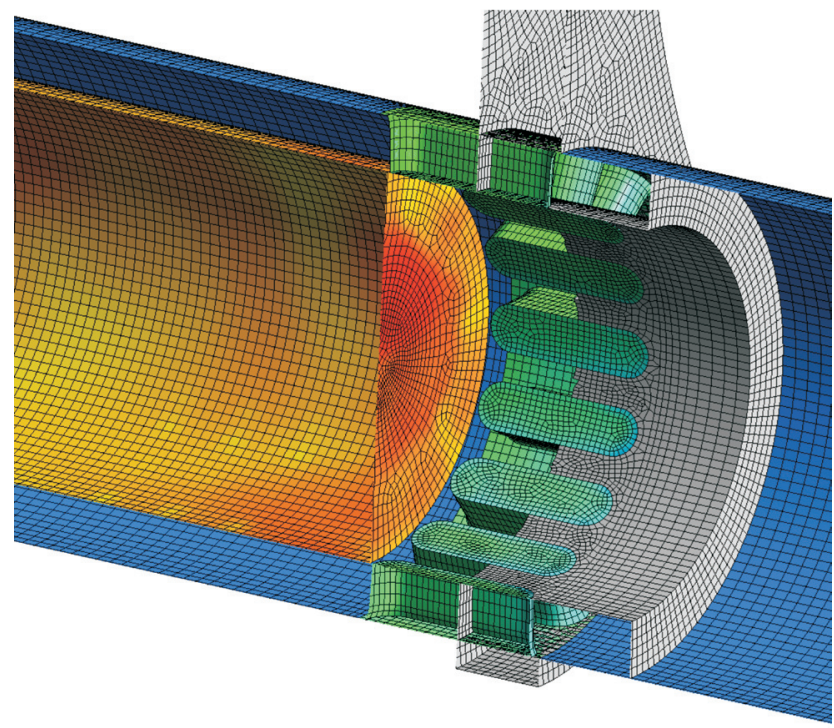

Fig. 5. Model A (full engine cycle simulation) - 3D mesh

Rys. 5. Model A (symulacja petnego cyklu pracy silnika)-dyskretyzacja przestrzenna

\section{Ustawienia symulacji CFD:}

Typ solvera - nieustalony, bazujący na ciśnieniu (Transient Pressure-Based)

Model turbulencji - standardowy SST k-omega

Ustawienia siatki - nabudowywanie siatki (layering) $\mathrm{z}$ własną funkcją ruchu

Schemat rozwiazania - Pressure-Implicit with Splitting of Operators (PISO)

Dyskretyzacja przestrzenna - domyślna

Sformułowanie zagadnienia nieustalonego - niejawna pierwszego rzędu (First Order Implicit + Non-Iterative Time-Advancement)

Krok czasowy -3600 kroków czasowych na cykl $\left(0,1^{\circ} \mathrm{OWK}\right)$

Domeny - płyn + ciało stałe 
the available computing power, thus a simplified workaround was proposed:

a) for every time step check where is the piston (knowing the piston motion function),

b) select the cells for which for current time step the $\mathrm{x}$-position is below the oil scrapping rings,

c) for selected cells read the current temperature and then replace stored therein heat flux to the one calculated using formula (1):

$$
\mathrm{q}_{\mathrm{n}}=-\alpha_{\text {oil }} \cdot\left(\mathrm{T}_{\text {current }}-\mathrm{T}_{\text {oilref }}\right)
$$

d) repeat for every time step, for every cell.

Time averaging. After considering oil impact heat flux profiles were averaged to reduce the number of boundary condition profiles for 3D unsteady solid heat transfer simulation (model B). Every 10 time steps were averaged into one, so finally there were 36 profiles/cycle.

\section{Solid body simulation}

Model B consisted exclusively of a solid domain.

\section{Mesh statistic:}

Cells (Fig. 6) $-\sim 383000$

Worst element orthogonal quality (Ansys Fluent) -0.16

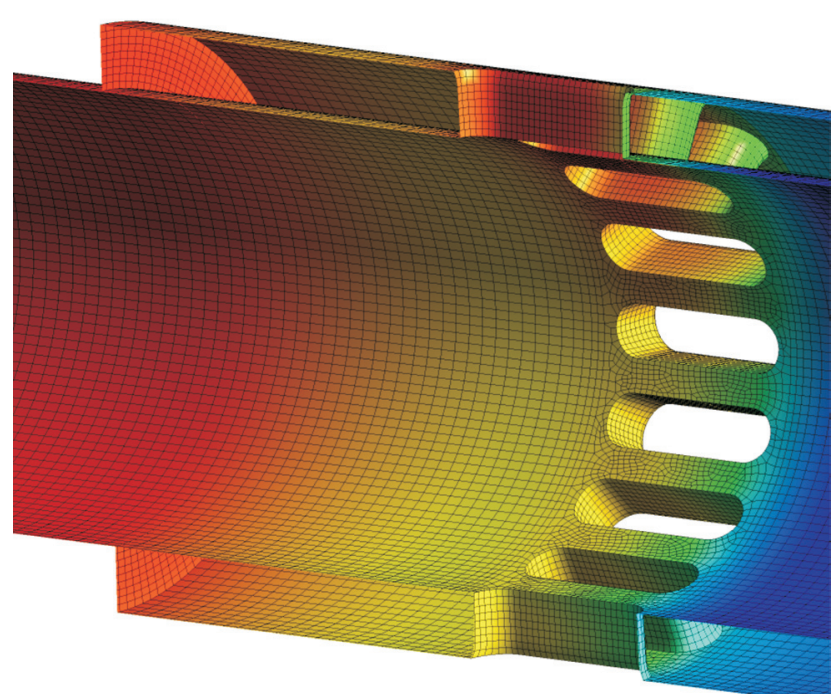

Fig. 6. Model B (solid body of the cylinder) - 3D mesh

Rys. 6. Model B (ciało stałe cylindra) - dyskretyzacja przestrzenna

\section{Solid CFD settings:}

Solver Type - Transient Pressure-Based

Material - Steel

Solving scheme-Semi-Implicit Method for Pressure-Linked

Equations (SIMPLE)

Spatial Discretization - default

Transient formulation - First Order Implicit

Time step - 36 timesteps/cycle

Domain - solid body

Solid model boundary conditions (Fig. 7, tab. 1):

Initially, there was only natural convection on the outer boundary with mixed boundary condition.
Szczegóły dotyczące podejścia do modelowania wymiany ładunku można znaleźć w pracy [6].

\section{Eksport strumieni ciepła oraz ich modyfikacja}

Podczas rozwiązywania pełnej, trójwymiarowej symulacji cyklu pracy silnika (model A) eksportowano z programu Ansys Fluent strumienie ciepła oraz rozkład temperatury na poszczególnych ściankach do zewnętrznych plików tekstowych co 10 kroków czasowych (1 $\left.{ }^{\circ} \mathrm{OWK}\right)$. Profile strumieni ciepła oraz temperatury były wczytywane do program Matlab oraz zapisywane w odpowiedniej strukturze zawierającej informacje o nazwie ścianki, aktualnym czasie, pozycji oraz wartości.

Olej smarujący gładź. Aby uwzględnić wpływ oleju smarującego $\mathrm{w}$ przestrzeni między tłokiem a cylindrem należałoby zdyskretyzować przestrzeń o wymiarach rzędu 0,03 mm co najmniej kilkoma elementami (przy średnicy cylindra około $50 \mathrm{~mm}$ ). Wynikowy rozmiar siatki uniemożliwiłby obliczenie takiego niestacjonarnego przypadku dostępnymi mocami obliczeniowymi, zaproponowano zatem rozwiązanie uproszczone:

a) dla każdego kroku czasowego sprawdź, gdzie znajduje się tłok (znając funkcję ruchu tłoka),

b) wybierz te komórki, dla których dla bieżącego kroku czasowego ich współrzędna $\mathrm{x}$ jest poniżej pierścieni zgarniających olej,

c) dla wybranych komórek odczytaj aktualną temperaturę, a następnie podmień zapisany w niej strumień ciepła na obliczony z zależności (1),

d) powtórz dla każdego kroku czasowego, dla każdej komórki.

Uśrednianie w czasie. Po uwzględnieniu wpływu oleju profile strumieni ciepła były uśredniane w czasie, aby zredukować liczbę warunków brzegowych dla trójwymiarowej nieustalonej symulacji wymiany ciepła w ciele stałym (model B). Każde 10 kroków czasowych zostało uśrednione do jednego, w związku z czym ostatecznie otrzymano 36 profili/cykl.

\section{Symulacja ciała stałego}

Model B składał się wyłącznie z domeny ciała stałego.

Statystyki siatki:

Objętości skończone (rys. 6) - 383000

Wskaźnik orthogonal quality (Ansys Fluent) dla najgorszego elementu -0.16

\section{Ustawienia symulacji CFD:}

Typ solvera - nieustalony, bazujący na ciśnieniu (Transient Pressure-Based)

Materiał - stal

Schemat rozwiązania - Semi-Implicit Method for PressureLinked Equations (SIMPLE)

Dyskretyzacja przestrzenna - domyślna

Sformułowanie zagadnienia nieustalonego - niejawna pierwszego rządu (First Order Implicit)

Krok czasowy - 36 kroków czasowych na cykl

Domeny - ciało stałe 


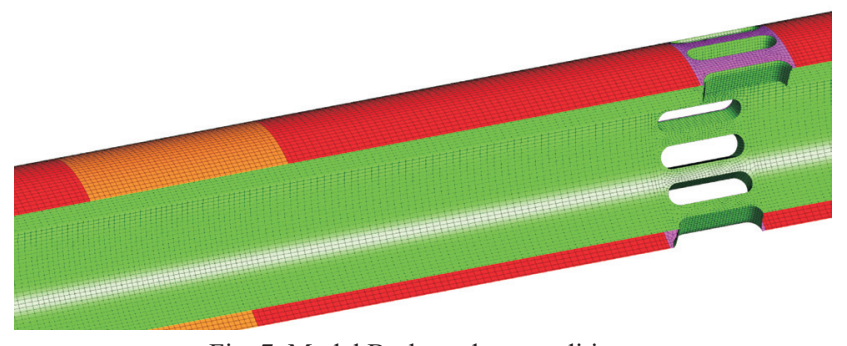

Fig. 7. Model B - boundary conditions Rys. 7. Model B-warunki brzegowe

Table 1. Boundary conditions overview

Tablica 1. Przegląd warunków brzegowych

\begin{tabular}{|c|c|c|}
\hline Color/kolor & BC Name/nazwa WB & Type/typ \\
\hline 1 & $\begin{array}{c}\text { Combustion chamber/ } \\
\text { komora spalania }\end{array}$ & $\begin{array}{c}\text { Mixed (HF + Emiss.)/ } \\
\text { mieszane }\end{array}$ \\
\hline 2 & $\begin{array}{c}\text { Outer liner/zewnętrza } \\
\text { powierzchnia }\end{array}$ & $\begin{array}{c}\text { Mixed (HF + Emiss.)/ } \\
\text { mieszane }\end{array}$ \\
\hline 3 & $\begin{array}{c}\text { Inner liner/wewnętrzna } \\
\text { powierzchnia }\end{array}$ & $\begin{array}{c}\text { Imported from Matlab/ } \\
\text { zaimportowane } \text { pro- } \\
\text { gram Matlab }\end{array}$ \\
\hline 4 & Exhaust/wylot & $\begin{array}{c}\text { Mixed (HF + Emiss.)/ } \\
\text { mieszane }\end{array}$ \\
\hline
\end{tabular}

Combustion chamber (1) + outer liner (2):

Heat Transfer Coefficient (HTC) $-30 \mathrm{~W} / \mathrm{m}^{2} \mathrm{~K}$

Free Stream Temperature $-340 \mathrm{~K}$

External Emissivity -0.8

External Radiation Temperature - $340 \mathrm{~K}$

Exhaust (4):

Heat Transfer Coefficient (HTC) $-80 \mathrm{~W} / \mathrm{m}^{2} \mathrm{~K}$

Free Stream Temperature $-800 \mathrm{~K}$

External Emissivity -0.8

External Radiation Temperature - $550 \mathrm{~K}$

For substitution of the temperature and heat transfer coefficients distribution the scripts written in Scheme were used. Scheme interpreter is embedded in the text command line (TUI) of Ansys Fluent. It allows some actions that are not possible to achieve even using their User Defined Functions.

Cylinder heating process. In the fig. 8 one can see the temperature distribution along the cylinder liner change in time for heat transfer coefficient obtained from $4^{\text {th }}$ iteration between model A and model B. Model with solid only (model B) was simulated for 1 minute. After 1500 cycles the temperature was exported to .ip Ansys Fluent interpolation file and used as a new temperature distribution for next scavenging calculation (model A).

It can be observed that the resulting temperature distribution in the combustion chamber (the area A in Fig. 8) is relatively constant around the circumference of the cylinder (narrow width of the black line in Fig. 8), while in the exhaust (area B) the asymmetric flow effect (Fig. 2) can be seen on the temperature distribution. Area $\mathrm{C}$, at which the temperature drops over time, indicates a strong influence of the initial overprediction of the temperature at that location. This results from that during the first iteration between model $\mathrm{A}$ and model $\mathrm{B}$ in the solid there was a low temperature in
Warunki brzegowe modelu ciala stałego (rys. 7, tab. 1): Wstępnie na zewnętrznej powierzchni założono wyłącznie konwekcję naturalną z mieszanymi warunkami brzegowymi.

Komora spalania (1) + zewnętrzna powierzchnia (2): Współczynnik przejmowania ciepła (HTC) $-30 \mathrm{~W} / \mathrm{m}^{2} \mathrm{~K}$ Temperatura odniesienia dla konwekcji (Free Stream Temperature) $-340 \mathrm{~K}$

Emisyjność (External Emissivity) -0.8

Temperatura odniesienia dla radiacji (External Radiation Temperature) $-340 \mathrm{~K}$

Wydech (4):

Współczynnik przejmowania ciepła (HTC) $-80 \mathrm{~W} / \mathrm{m}^{2} \mathrm{~K}$ Temperatura odniesienia dla konwekcji (Free Stream Temperature $)-800 \mathrm{~K}$

Emisyjność (External Emissivity) - 0.8

Temperatura odniesienia dla radiacji (External Radiation Temperature) $-550 \mathrm{~K}$

Do podmiany rozkładów temperatury i współczynników przejmowania ciepła używano skryptów języka Scheme, którego interpretator jest wbudowany w tekstową linię komend (TUI) programu Ansys Fluent. Umożliwia on pewne akcje, które nie są możliwe do uzyskania nawet za pomocą funkcji własnych użytkownika (User Defined Functions).

Proces ogrzewania cylindra. Na rysunku 8 można prześledzić zmianę rozkładu temperatury wzdłuż cylindra w czasie dla współczynników przejmowania ciepła uzyskanych po 4. iteracji między modelem A oraz modelem B. Model z samym ciałem stałym (model B) był symulowany przez 1 minutę. Po 1500 cyklach temperatura została wyeksportowana do pliku interpolacyjnego .ip programu Ansys Fluent oraz ustalona jako rozkład temperatury dla kolejnej symulacji wymiany ładunku (model A).

Analiza rysunku wskazuje, że uzyskany rozkład temperatury w komorze spalania (obszar A na rys. 8) jest prawie stały po obwodzie cylindra (mała szerokość czarnej linii na rys. 8), natomiast na wydechu (obszar B) widać duży wpływ niesymetryczności przepływu (rys. 2) na rozkład temperatury. Obszar C, na którym z biegiem czasu spada temperatura, świadczy o silnym wpływie wstępnego przeszacowania temperatury w tamtym miejscu. Wynika to $\mathrm{z}$ tego, iż podczas pierwszych iteracji między modelem $\mathrm{A}$ a modelem $\mathrm{B}$ w ciele stałym występowała w tamtym rejonie niska temperatura, dlatego pierwsze wyeksportowane wyniki współczynników wymiany ciepła były przeszacowane. Przebieg zmiany temperatury w czasie można prześledzić na rys. 11.

\section{Podejście iteracyjne}

Po ponownym uruchomieniu symulacji wymiany ładunku (model A) z nowym rozkładem temperatury zaimportowanym z pliku interpolacyjnego wyznaczono nowe profile strumieni ciepła oraz wyeksportowano je przez pliki ASCII do programu Matlab. Skrypt programu Matlab dokonał modyfikacji, a następnie eksportował profile strumieni ciepła do modelu ciała stałego (model B), gdzie program Ansys Fluent dokonywał obliczeń przez kolejne 1500 cykli (minutę pracy silnika). Ta procedura była powtarzana dopóty, dopóki temperatura nie przestała się zmieniać znacząco (przyjęto 
that region, and therefore the first exported heat transfer coefficients were overestimated. The temperature variation in the time can be seen in Fig. 11.

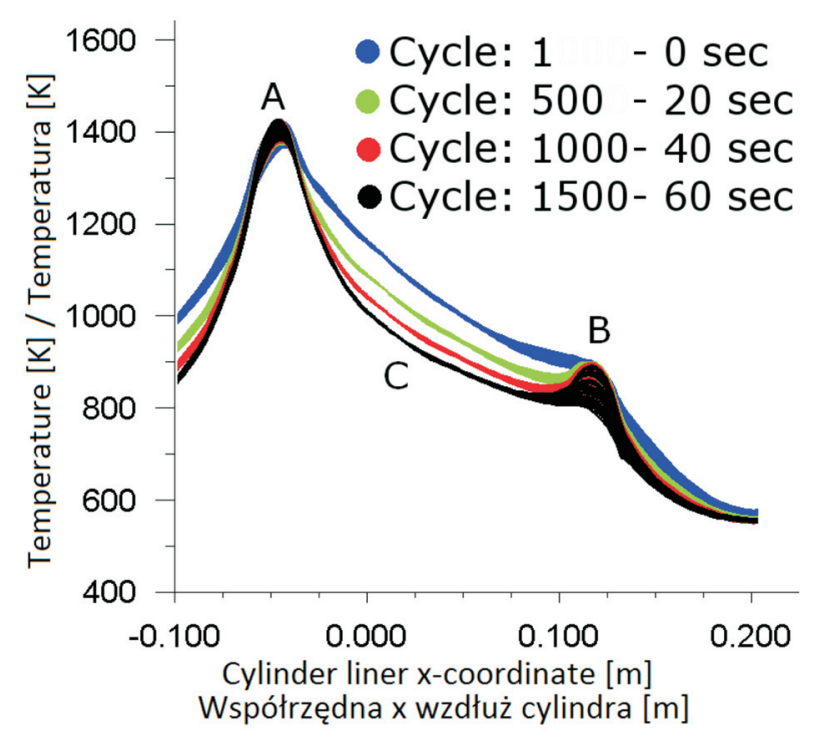

Fig. 8. Solid model heating: 4 time points, temperature [K] distribution along cylinder liner [m]

Rys. 8. Ogrzewania ciała stałego, 4 punkty czasowe, rozkład temperatury [K] wzdtuż cylindra [m]

\section{Iterative approach}

After restarting the scavenging simulation (model A) with a new temperature distribution imported from the interpolation file the updated heat fluxes and temperatures were calculated and exported through ASCII files to Matlab. Matlab modified results and then exported them to the solid body model (model B) which Ansys Fluent was solving for another 1500 cycles ( $1 \mathrm{~min}$ of the engine work). This procedure has been repeated until the temperature stopped changing significantly (the threshold was set by no more than $5 \mathrm{~K}$ per 1 minute work of solid body model - model B). Diagram of the calculation algorithm is illustrated in the Fig. 9.

In the Fig. 10 the temperature contours in the XY crosssection through a part of the engine are visualized. It can be observed that the iterations caused the temperature to move gradually towards the cylinder combustion chamber (zone A) and the exhaust channels (zone B). Importantly, it can be seen that changes of the temperature of the cylinder did not significantly affect the scavenging. Mixing front after the closure of the ports (zone C) is the same for iteration 1,3 and 5 between model A and model B. This confirms that for the scavenging the most important effects are the ones related to the inertia of the fluid caused by the pressure difference between intake ( 1 in Fig. 1) and exhaust (4 in Fig. 1).

Fig. 11 shows the resulting temperature distributions obtained after iteration accordingly to the workflow presented in the Fig. 9. For the next iteration it is meant to: calculate a complete próg nie więcej niż $5 \mathrm{~K}$ podczas minuty pracy w modelu ciała stałego - modelu B). Schemat procesu postępowania zilustrowano na rys. 9.

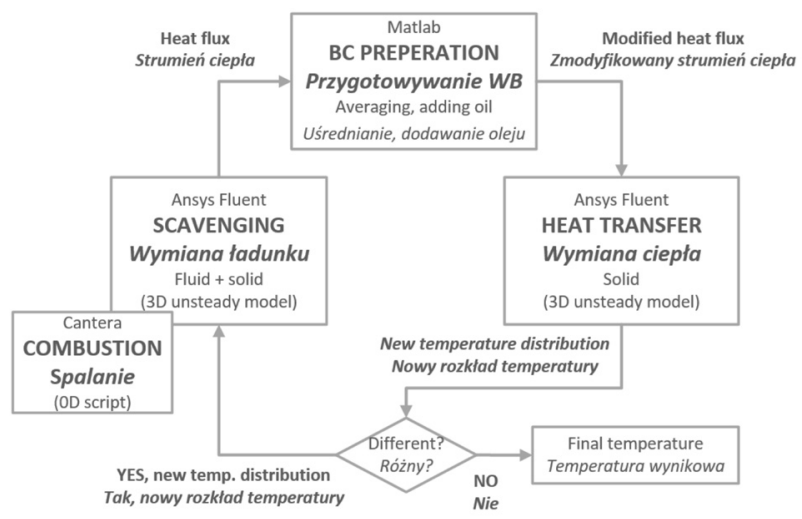

Fig. 9. Iterative cylinder temperature calculation algorithm Rys. 9. Algorytm iteracyjnej metody wyznaczania temperatury cylindra

$\mathrm{Na}$ rysunku 10 zwizualizowano kontury temperatury w przekroju XY przez fragment silnika. Można zaobserwować, że kolejne iteracje powodowały stopniowe przesuwanie się temperatury w kierunku komory spalania (strefa A) oraz kanałów wylotowych (strefa B). Ponadto zauważa się, że zmiany temperatury cylindra nie wpływały znacząco na wymianę ładunku. Czoło mieszania po zamknięciu kanałów (strefa C) jest takie samo dla iteracji 1, 3 oraz 5 między modelem A modelem B. Potwierdza to, że podczas wymiany ładunku najistotniejsze są efekty związane z bezwładnością płynu wywołane różnicą ciśnień między przelotnią (1 na rys. 1) oraz wydechem (4 na rys. 1).

Na rysunku 11 przedstawiono wynikowe rozkłady temperatur po iteracjach uzyskiwanych zgodnie $\mathrm{z}$ algorytmem zaprezentowanym na rys. 9. Przez kolejną iterację rozumie się: obliczenie pełnego cyklu pracy silnika w modelu A, a następnie obliczenie rozkładu temperatury w modelu B. Można zaobserwować, że przy kolejnych iteracjach niesymetryczność przepływu przez kanały wydechowe (rys. 2) jest

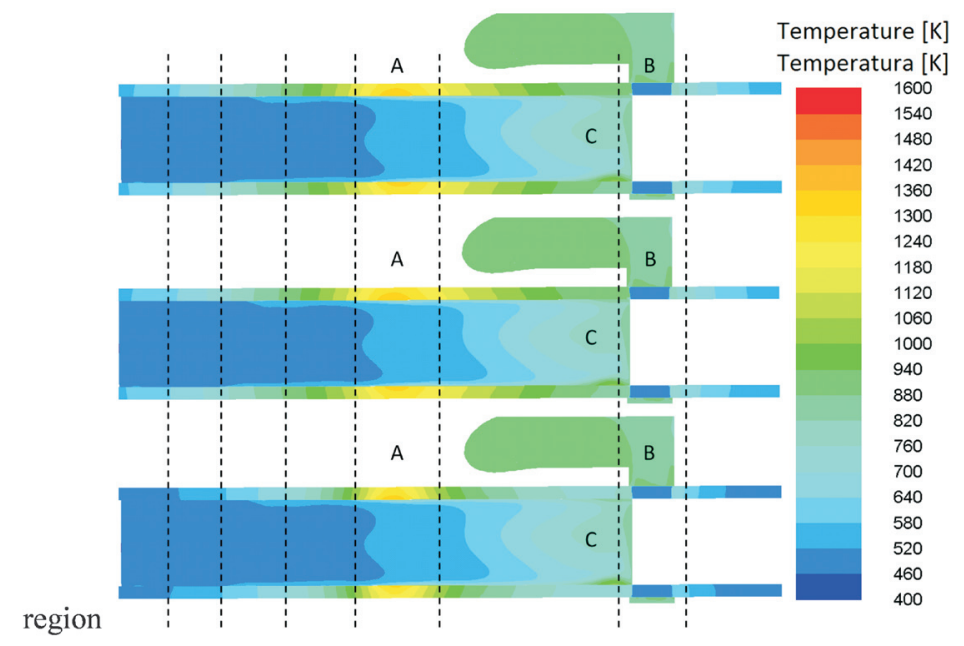

Fig. 10. Contour temperature distribution for iteration 1, 3 and 5 Rys. 10. Rozkład temperatury dla iteracji 1, 3 oraz 5 


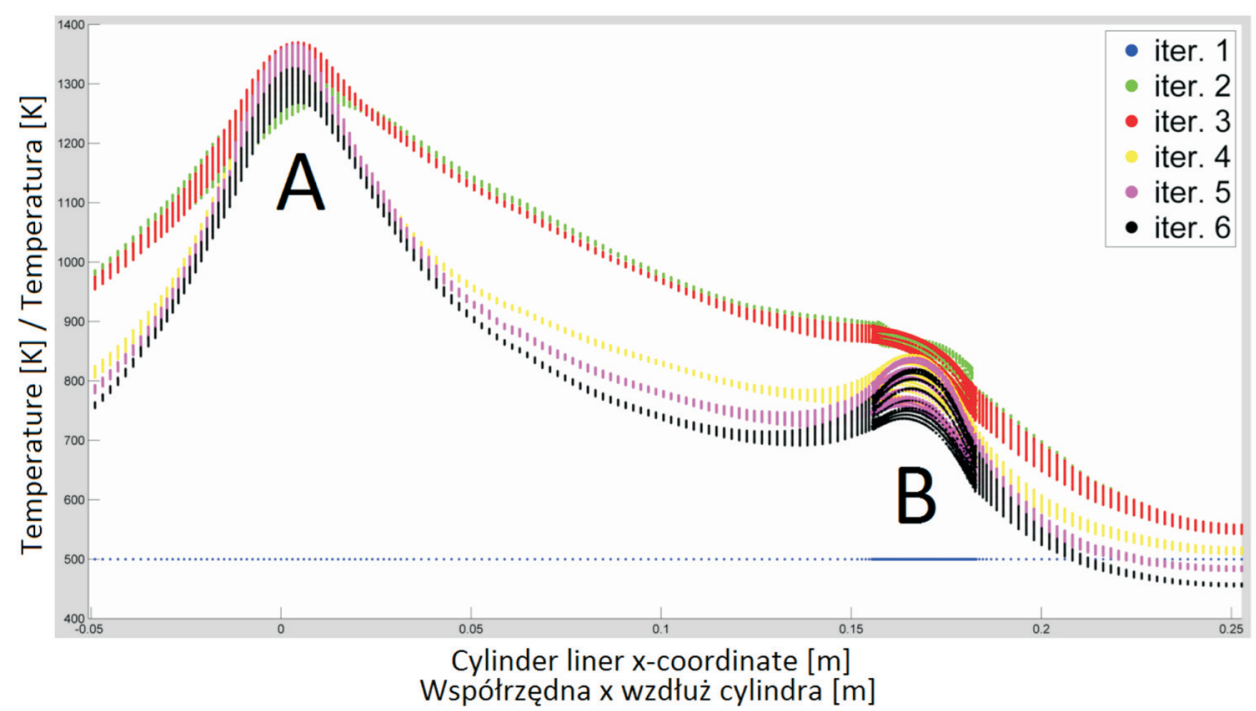

Fig. 11. Temperature distribution $[\mathrm{K}]$ along cylinder liner for iterations 1-6 Rys. 11. Rozktad temperatury [K] wzdluz cylindra dla iteracji 1-6 coraz lepiej odwzorowywana $\mathrm{w}$ rozkładzie temperatury (strefa B, rys. 11). W komorze spalania (strefa A) temperatura jest w miarę wyrównana, na obwodzie temperatury różnią się maksymalnie o $70 \mathrm{~K}$.

\section{Podsumowanie uzyskanych wyników}

Rozkład temperatury dla niechłodzonego cylindra przedstawiono na rys. 12. Mostki kanałów wylotowych mają bardzo wysoką temperaturę maksymalną (wyższą niż $800 \mathrm{~K}$ ) oraz gradienty temperatury sięgające $200 \mathrm{~K}$, co skutkuje bardzo dużymi naprężeniami termomechanicznymi. Na podstawie tego można wywnioskować, że mostki kanałów będą musiały być bardzo chłodzone.

Piki temperatury w komorze spalania osiągają $1300 \mathrm{~K}$ (rys. 11), co jest znacznie powyżej limitów dla jakiejkolwiek stali dla pracy ciągłej. Konieczne jest w związku z tym zaimplementowane chłodzenia płaszczem wodnym w celu redukcji temperatury oraz wyrównania temperatury po obwodzie komory spalania.

Temperatura powierzchni cylindra jest powyżej limitu projektowego (523 K - temperatura degradacji filmu olejowego). Po dokonaniu obliczeń modelu z płaszczem wodnym w okolicach kanałów wylotowych oraz komory spalania będzie można oszacować czy koniecznie jest dodatkowe chłodzenie powierzchni cylindra, czy też nie. temperature gradients are reaching $200 \mathrm{~K}$, which results very high thermomechanical stresses. It can be observed that port bridges will have to be heavily cooled.

The temperature peaks in the combustion chamber reaches $1300 \mathrm{~K}$ (Fig. 11), which is well above the limits for any steel for continuous operation. It is therefore necessary to implement a water cooling jacket to reduce the temperature and balance the temperature distribution on the circumference of the combustion chamber.

Additionally, the cylinder liner temperature is above the design limit $(523 \mathrm{~K}$ - temperature of the oil film degradation). After calculating the model with the water jacket in the vicinity of the exhaust ports and the combustion chamber it could be estimated whether it is necessary to further cool the cylinder liner or not.

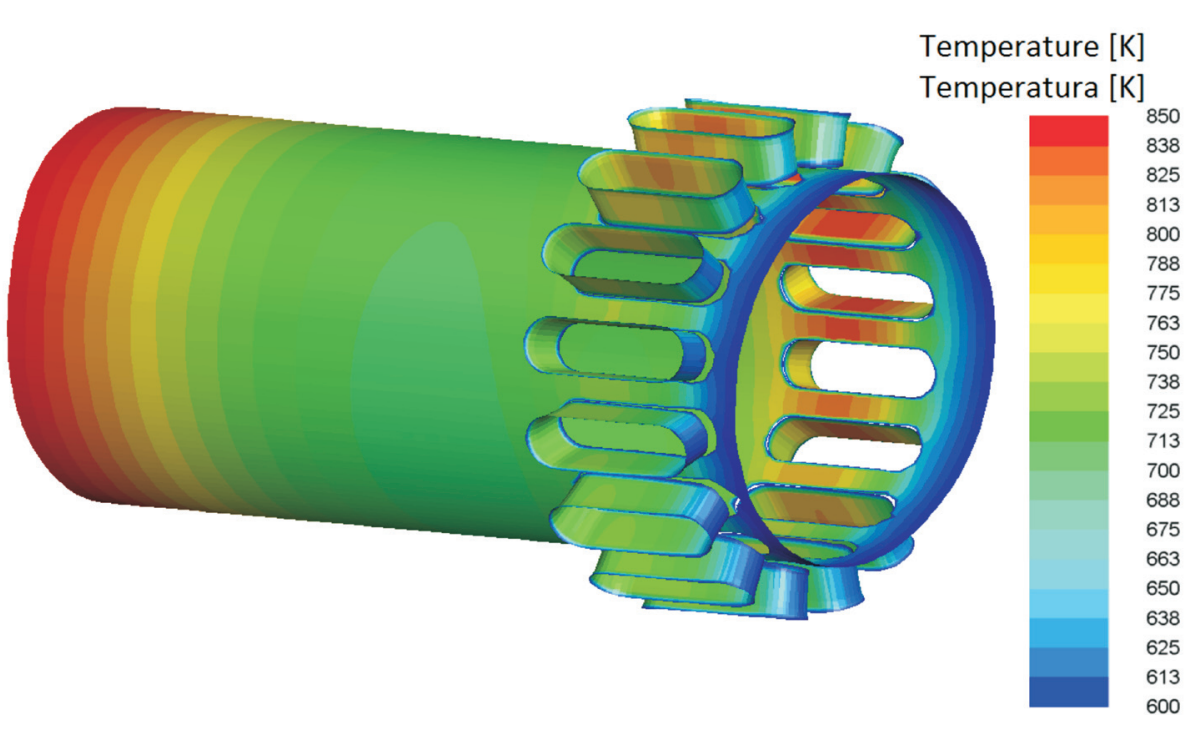

Fig. 12. Temperature distribution [K] near exhaust ports for non-cooled solution Rys. 12. Rozkład temperatury [K] w pobliżu kanałów wylotowych dla niechłodzonej wersji 


\section{Discussion and conclusions}

Authors presented a solution for modeling a heat transfer (defined in this article as a determination of the temperature fields) in an opposed piston engine. Commercial calculation code has been used and complemented by proprietary scripts. Because this method was not validated with the results of the engine research on a dynamometer, at this stage it should be regarded as a tool for qualitative comparison of different concepts of cooling systems in order to find the best. Further work will be focused on validating the obtained solution to legitimize the results quantitatively. In addition, the authors want to further optimize the developed code by calculation parallelization.

\section{Acknowledgments}

Presented work is a part of the research which received funding from the Polish-Norwegian Research Program operated by the National Centre of Research and Development under the Norwegian Financial Mechanism 2009-20014 in the frame of Project Contract No Pol-Nor/199058/94

\section{Podsumowanie}

Zaprezentowano rozwiązanie do modelowania wymiany ciepła (rozumianej w tym artykule jako wyznaczanie pól temperatury) w silniku o tłokach przeciwbieżnych. Wykorzystano komercyjny kod obliczeniowy wzbogacony autorskimi skryptami. Ponieważ metoda ta nie została zwalidowana dotychczas wynikami badań silnika na hamowni, na tym etapie należy ją traktować jako narzędzie do porównania jakościowego różnych koncepcji układów chłodzenia w celu znalezienia najlepszego. Dalsza praca będzie polegała na walidacji otrzymanych rozwiązań, aby usankcjonować wyniki ilościowo. Ponadto autorzy artykułu chcą dalej optymalizować opracowany kod przez zrównoleglenie obliczeń.

\section{Podziękowania}

Zaprezentowany artykuł jest częścią prac projektu, który otrzymał dofinansowanie w ramach Polsko-Norweskiej Współpracy Badawczej finansowanej przez Narodowe Centrum Badań i Rozwoju w ramach Norweskiego Mechanizmu Finansowego 2009-2014 na podstawie kontraktu Pol-Nor/199058/94.

\section{Bibliography/Literatura}

[1] Gatowski, J.A. et al. Heat Release Analysis of Engine Pressure Data, SAE Technical Paper 841359, 1984.

[2] Hayes, T.K., Savage, L.D, Sorenson, S.C. Cylinder Pressure Data Acquisition and Heat Release Analysis on a Personal Computer, SAE Technical Paper 860029, 1986.

[3] Heywood, J.B. Internal Combustion Engines, McGraw-Hill, 1988.

[4] Hirsch, Ch. Numerical Computation of Internal and External Flows, Oxford, 2007.

[5] Hohenberg, G.F. Advanced Approaches for Heat Transfer Calculations, SAE Technical Paper 790825, 1979.

Jakub Kalke, MSc Eng. - PhD student in the Faculty of Power and Aeronautical Engineering at Warsaw University of Technology.

mgr inż. Jakub Kalke - doktorant na Wydziale Mechanicznym Energetyki i Lotnictwa Politechniki Warszawskiej

e-mail: jakub.kalke@itc.pw.edu.pl

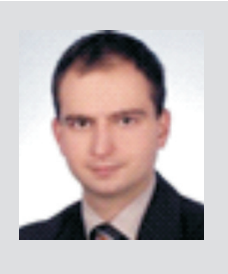

Mateusz Szczeciński, MSc, Eng. - PhD student in the Faculty of Power and Aeronautical Engineering at Warsaw University of Technology.

mgr inż. Mateusz Szczeciński - doktorant na Wydziale Mechanicznym Energetyki i Lotnictwa Politechniki Warszawskiej.

e-mail:mszczecinski@itc.pw.edu.pl

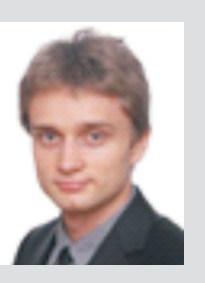

[6] Kalke, J., Sulikowski, P., Mazuro, P. Development of the numerical scavenging process analysis in opposed-piston engines, Combustion Engines. 2015, 162(3).

[7] Lee, P., Wahl, M. Cylinder Cooling for Improved Durability on an Opposed-Piston Engine, SAE Technical Paper 2012-01$1215,2012$.

[8] Niewiarowski, K. Tłokowe silniki spalinowe, Warszawa, Wydawnictwa Komunikacji i Łączności, 1983.

[9] Pirault, J.P., Flint, M. Opposed Piston Engines: Evolution, Use, and Future Applications, SAE International, 2009.

[10] Randy, E.H. et al. Thermodynamic Benefits of Opposed-Piston Two-Stroke Engines, SAE Technical Paper 2011-01-2216, 2011.

[11] Wallace, F., Cave, P. Experimental and Analytical Scavenging Studies on a Two-Cycle Opposed Piston Diesel Engine, SAE Technical Paper 710175, 1971.

[12] Woschni, G. Die Berechnung Wer Wandverluste und der thermichen Belastung der Bauteile von Dieselmotoren, MTZ 1970, 31.

Paweł Mazuro, DEng. - assistant professor at the Faculty of Power and Aeronautical Engineering at Warsaw University of Technology.

dr inż. Pawel Mazuro - adiunkt na Wydziale Mechanicznym Energetyki i Lotnictwa Politechniki Warszawskiej.

e-mail:pawel.mazuro@itc.pw.edu.pl 